\title{
臍帯血幹細胞移植 一同種移植およびバンクへの可能性一
}

神奈川県立こども医療センター腫瘍科，*同 血液科 西平 浩一 本多康次郎* 豊田 恭徳

\section{1. 臍帯血幹細胞移植の理論的根拠}

骨髄移植に代表される造血幹細胞移植療法（以下， 幹細胞移植）は造血幹細胞を移植し生着させることで ある。

最近，造血幹細胞の新たな供給源として臍帯血中の 幹細胞が注目されている ${ }^{12)}$. 胎盤は分婏後は無用のも ので, 廃棄処分されている. しかし，その胎盤に残っ ている臍帯血を採取し，その中に含まれる幹細胞を移 植して骨髄造血機能を再生させるのが臍帯血幹細胞移 植である.1989年に臍帯血幹細胞移植を行った第一例 が報告され ${ }^{3)}$, その後, 臍帯血幹細胞移植の症例は増加 し,1994年12月までに欧米を中心に60例に達している. そこで，まず臍帯血の幹細胞が骨髄の代わりになり得 る理由をごく簡単に述べます。

一般に幹細胞移植療法に際しては移植する幹細胞の 質的および量的なことが重要である。臍帯血には増殖 能の高い幹細胞が多数あること，量的な面では骨髄ほ ぞ多量に採取できないが，一つの胎盤䐮帯の血液から 小児の移植に足りる幹細胞数が採取可能であることが その理由である。

現在は幹細胞数は幹細胞コロニー形成法による顆粒 球系幹細胞 (CFU-GM : Colony Forming UnitGranulocyte, Macrophage), 赤血球系幹細胞 (BFUE : Burst Forming Unit-Erythroid), 巨核球系幹細胞 (CFU-MK : Colony Forming Unit-Megakaryocyte), 混合コロニー (CFU-mix) の数を参考にし, 特に, CFU-GM 数が標準的指標にされている.そこで臍帯血 と骨髄のこれら幹細胞をコロニー形成法で比較検討し た成績を述べる。

\section{2. 臍帯血幹細胞の質的特徵}

\section{一増殖能よりみた骨髄細胞との比較一}

1）臍帯血の造血幹細胞コロニーの特徵

幹細胞コロニー形成法により検討した臍帯血幹細胞 (cord blood stem cells) の特徴は小児や成人の骨髄の それに比し増殖能が著しく高いことである，われわれ の検討した成績の概要は次のとおりである.

コロニー形成法はメチルセルロース法で，コロニー
刺激因子として G-CSF, erythropoietin, interleukin3 (IL-3), Stem cell factor（SCF）を使用した。臍帯 血は婏出直後の胎般臍帯血管より採取した. 対象とし た骨髄は血液学的に異常のない検体である。

臍帯血由来コロニーは骨髄のそれに比較して, 著し く大きなものが多数を占めており, 顕微鏡を使用しな くてもコロニーの種類がほぼ区別できるほどである. これらのことは増殖能の高い幹細胞が多数存在してい ることを示唆している4).

液体培養による幹細胞数の増加率：in vitro での液 体培養によるコロニー数の増加率につき臍帯血, 骨髄 それぞれ 7 例を検討したわれわれの成績では, rIL-3を 添加した液体培養後のコロニー数の増加率でみると, 臍帯血では増加率は4.6倍から22.7倍, 平均10.7倍で あった。一方, 骨髄では平均 2.6 倍であり, 臍帯血は骨 髄よりも約 4 倍高い増殖能がみられた4).

その他多数の報告のうち, Hows ら ${ }^{5)}$ 臍帯血には 未分化な細胞よりなるコロニーが多く, 長期培養が可 能で, 量的ならびに質的に骨髄よりも幹細胞供給源と して優れていると述べている，臍帯血と骨䯣細胞を液 体培養で比較検討し, 臍帯血では 3 力月以上も顆粒球 の增殖がみられたが, 成人の骨髄や末梢血では $2 \sim 3$ 週後は増殖がみられなくなったとの報告, 臍帯血では 液体培養 6 週後も CFU-mix をはじめ各種コロニーが 検出されたとの報告もある.

このように臍帯血には骨髄に比し増殖能の高い未分 化な幹細胞が多数存在していることは幹細胞移植に利 用するに極めて有利なことである.

以上，幹細胞の質的な面で骨髄より優れていること を述べた。

\section{3. 胎盤臍帯血の幹細胞の密度}

新生児には成人に比し末梢血液 $1 \mathrm{~m} l$ 中の幹細胞数 は著しく増加していることは以前から知られていた。 われわれも1977年に在胎週数の少ない未熟児末梢血液 には成人の約 100 倍の濃度で CFU-GM が存在するこ とを報告した。新生児末梢血液と臍帯血は必ずしも同 一ではないが生後24時間以内ならほほ同等と思われ 


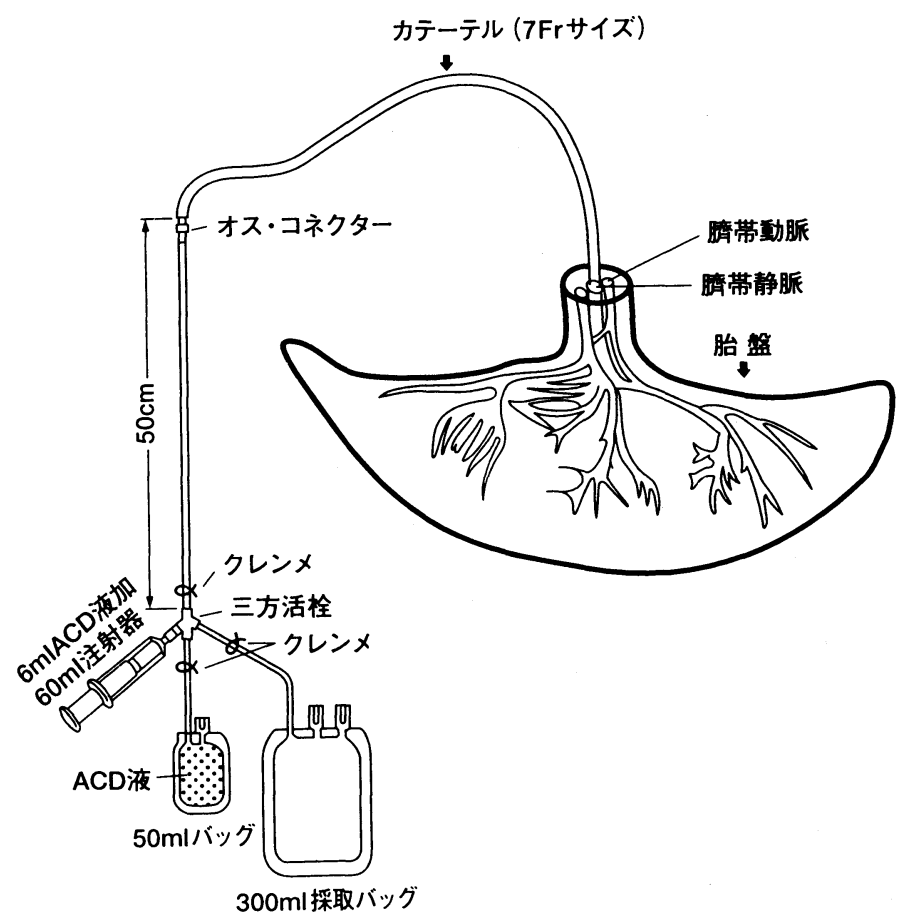

図 1 胎盤臍帯血採取法

神奈川県立こども医療センター方式

る.

最近われわれは在胎週数別の臍帯血あるいは新生児 末梢血液の $1 \mathrm{~m} l$ 中に含まれる CFU-GM, BFU-E, CFU-mix の数を検討し在胎週数と相関関係がみられ ること,また多量の幹細胞が存在しており, 臨床的に 幹細胞移植への応用が可能であることを示した ${ }^{4)}$.

\section{4. 胎盤臍帯血の採取法と移植に 必要な幹細胞の採取}

1）胎盤臍帯血採取法

臍帯血採取は図 1 に示した臍帯血採取セットを使用 して行った．方法の概略を以下に述べる。すなわち， 胎盤婏出直後に $10 \%$ イソジン液で胎盤全体を消毒し， 胎盤近位で臍帯を切断した。臍帯結紮は通常の分婏と 同様に行い, 臍帯静脈に7Fr のカテーテルを挿入する. $\mathrm{ACD}$ 液加シリンジで血液を吸引儿採血バックに採取 する方法である。

2) 臍帯血採取量

i）検討された 30 検体では臍帯血採取血液量は $30 \sim 180 \mathrm{~m} l$ (median $80 \mathrm{~m} l$ ) であり, 有核細胞総数は 1.5〜 $11.6 \times 10^{8}$ (median $4.15 \times 10^{8}$ ) であった。

ii ）採取された臍帯血幹細胞総数
一つの胎盤から一人の患者の移植に必要な幹細胞が 採取可能か否かにつき, 胎盤28検体を対象に検討し $た^{6}$. 幹細胞数は CFU-GM, BFU-E, CFU-mix の各コ ロニー数で示した. 表 1 に示したようにCFU-GM 数 は1. $5 \times 10^{5} \sim 33.1 \times 10^{5}$ (median $5.3 \times 10^{5}$ ) であり, BFU.E 数は $1.1 \times 10^{5} \sim 22.7 \times 10^{5}$ (median $5.7 \times 10^{5}$ ), CFU-mix は $0.15 \times 10^{5} \sim 2.7 \times 10^{5}$ (median $0.72 \times 10^{5}$ ) であった。

Gluckman らの報告では採取された CFU-GM コロ ニー数は平均 $2.4 \times 10^{5}$ であったので, これとほほ同程 度の採取量であった ${ }^{7)}$.

最近 human thrombopoietin (hTPO) のクローニン グが成功し, recombinant hTPO を使用した培養では 巨核球コロニー (CFU-MK) 数は $50 \sim 150 / 10^{5}$ 有核細胞 であり，骨髄に存在する CFU-MK コロニー数よりも 高頻度にみられた。 また, 図 2 に示すようにコロニー を構成する巨核球は数千個以上であり, 骨髄由来の CFU-MK の10倍以上の大きさであった.

iii）幹細胞移植に必要な幹細胞数

これまで報告されている臍帯血幹細胞移植例では移 植に必要な CFU-GM 数は体重あたり $2 \times 10^{4} \sqsupset / \mathrm{kg}$ 
表 1 胎盤臍带より採取可能幹細胞総数

\begin{tabular}{|c|c|c|c|c|}
\hline \multirow{2}{*}{$\mathrm{CB}$} & \multirow{2}{*}{ NCC } & \multicolumn{3}{|c|}{ Total Number of Colonies } \\
\hline & & CFU-GM & BFU-E & CFU-mix \\
\hline 1. & $3.4 \times 10^{8}$ & $3.5 \times 10^{5}$ & $4.6 \times 10^{5}$ & $0.55 \times 10^{5}$ \\
\hline 2. & $2.4 \times 10^{8}$ & $3.1 \times 10^{5}$ & $1.1 \times 10^{5}$ & $0.34 \times 10^{5}$ \\
\hline 3. & $1.8 \times 10^{8}$ & $4.9 \times 10^{5}$ & $6.8 \times 10^{5}$ & $0.71 \times 10^{5}$ \\
\hline 4. & $10.8 \times 10^{8}$ & $33.1 \times 10^{5}$ & $20.5 \times 10^{5}$ & $2.7 \times 10^{5}$ \\
\hline 5. & $7.6 \times 10^{8}$ & $14.9 \times 10^{5}$ & $11.9 \times 10^{5}$ & $1.07 \times 10^{5}$ \\
\hline 6. & $1.3 \times 10^{8}$ & $11.5 \times 10^{5}$ & $22.7 \times 10^{5}$ & $2.38 \times 10^{5}$ \\
\hline 7. & $3.2 \times 10^{8}$ & $5.9 \times 10^{5}$ & $7.0 \times 10^{5}$ & $0.56 \times 10^{5}$ \\
\hline 8. & $3.6 \times 10^{8}$ & $2.9 \times 10^{5}$ & $1.2 \times 10^{5}$ & $0.15 \times 10^{5}$ \\
\hline 9. & $2.5 \times 10^{8}$ & $1.5 \times 10^{5}$ & $1.7 \times 10^{5}$ & $0.23 \times 10^{5}$ \\
\hline 10. & $5.6 \times 10^{8}$ & $5.6 \times 10^{5}$ & $3.0 \times 10^{5}$ & $0.73 \times 10^{5}$ \\
\hline 11. & $6.5 \times 10^{8}$ & $2.2 \times 10^{5}$ & $1.7 \times 10^{5}$ & $0.31 \times 10^{5}$ \\
\hline 12. & $4.5 \times 10^{8}$ & $2.5 \times 10^{5}$ & $3.5 \times 10^{5}$ & $0.58 \times 10^{5}$ \\
\hline 13. & $9.2 \times 10^{8}$ & $10.2 \times 10^{5}$ & $9.4 \times 10^{5}$ & $1.50 \times 10^{5}$ \\
\hline 14. & $8.1 \times 10^{8}$ & $4.1 \times 10^{5}$ & $3.8 \times 10^{5}$ & $0.40 \times 10^{5}$ \\
\hline 15. & $9.8 \times 10^{8}$ & $5.3 \times 10^{5}$ & $4.1 \times 10^{5}$ & $0.50 \times 10^{5}$ \\
\hline 16. & $2.3 \times 10^{8}$ & $1.5 \times 10^{5}$ & $2.2 \times 10^{5}$ & $0.35 \times 10^{5}$ \\
\hline 17. & $4.0 \times 10^{8}$ & $1.8 \times 10^{5}$ & $4.0 \times 10^{5}$ & $0.65 \times 10^{5}$ \\
\hline 18. & $13.0 \times 10^{8}$ & $13.5 \times 10^{5}$ & $11.2 \times 10^{5}$ & $4.80 \times 10^{5}$ \\
\hline 19. & $4.6 \times 10^{8}$ & $2.9 \times 10^{5}$ & $4.1 \times 10^{5}$ & $0.64 \times 10^{5}$ \\
\hline 20. & $4.8 \times 10^{8}$ & $0.8 \times 10^{5}$ & $1.4 \times 10^{5}$ & $0.24 \times 10^{5}$ \\
\hline 21. & $11.5 \times 10^{8}$ & $6.4 \times 10^{5}$ & $8.1 \times 10^{5}$ & $4.95 \times 10^{5}$ \\
\hline 22. & $9.6 \times 10^{8}$ & $3.0 \times 10^{5}$ & $4.1 \times 10^{5}$ & $1.70 \times 10^{5}$ \\
\hline 23. & $7.4 \times 10^{8}$ & $6.7 \times 10^{5}$ & $5.8 \times 10^{5}$ & $2.07 \times 10^{5}$ \\
\hline 24. & $9.7 \times 10^{8}$ & $5.4 \times 10^{5}$ & $7.3 \times 10^{5}$ & $3.00 \times 10^{5}$ \\
\hline 25. & $12.4 \times 10^{8}$ & $11.7 \times 10^{5}$ & $9.6 \times 10^{5}$ & $3.94 \times 10^{5}$ \\
\hline 26. & $1.6 \times 10^{8}$ & $2.3 \times 10^{5}$ & $1.7 \times 10^{5}$ & $0.51 \times 10^{5}$ \\
\hline 27. & $9.8 \times 10^{8}$ & $3.3 \times 10^{5}$ & $5.4 \times 10^{5}$ & $1.90 \times 10^{5}$ \\
\hline 28. & $16.3 \times 10^{8}$ & $28.2 \times 10^{5}$ & $35.1 \times 10^{5}$ & $7.23 \times 10^{5}$ \\
\hline Range. 1 & $3 \sim 16.3 \times 10^{8}$ & $0.8 \sim 33.1 \times 10^{5}$ & $1.2 \sim 35.1 \times 10^{5}$ & $0.15 \sim 7.23 \times 10^{5}$ \\
\hline Median & $5.2 \times 10^{8}$ & $4.5 \times 10^{5}$ & $4.1 \times 10^{5}$ & $0.57 \times 10^{5}$ \\
\hline
\end{tabular}

CB : cord blood, NCC : nucleated cell count

が標準的な数とされている われの採取量は体重20～30kg 以下の患者に対しては 移植に必要な幹細胞は得られたと思われる。すでに一 般に行われている同種骨髄移植や未梢血幹細胞移植で は CFU-GM 数は $10^{5} / \mathrm{kg}$ が必要とされているので, 臍 帯血幹細胞移植ではその 5 分の 1 または 10 分の 1 で足 りることになる，また，有核細胞数で比較しても同種 骨髄移植の $3 \times 10^{3} / \mathrm{kg}$ に対し, 臍帯血では $4 \times 10^{7} / \mathrm{kg}$ と約 10 分の 1 で生着している.このように，小児期に おける幹細胞移植の対象となる患者では臍帯血でも十 分骨髄再構築が可能と思われる.

\section{5. 臍帯血幹細胞移植の現状}

Gluckman らは1989年に臍帯血幹細胞移植を行った 第一例を報告している ${ }^{3)}$. 症例は 5 歳の男児, 疾患は
Fanconi 貧血, 妹の臍帯血幹細胞を移植し生着が得ら れ，原疾患も治癒している。

その後, 臍帯血幹細胞移植の症例は増加し，1993年 9 月までに米国 Indiana 大学を中心とした研究グルー プのまとめでは, 50例に達している ${ }^{8}$. その成績の概要 は次のとおりである，対象疾患は悪性腫瘍，30例，非 腫瘍性疾患, 20例. 臍帯血のドナーの種類および HLA は, 同胞間44例(HLA 一致, $34 ； 1 \sim 3$ 座不一致10), 非血縁者間 6 例(HLA 一致，1；1～2 座不一致，5) である. 移植を受けた患者の年齢は 1 歳 3 力月から 47 歳, 体重は $7 \sim 98 \mathrm{~kg}$ (中央値 $20 \mathrm{~kg}$ ) であった. 移植 された有核細胞数の中央値は $4 \times 10^{7}$ (range $0.8 \times 10^{7}$ $\sim 33 \times 10^{7} / \mathrm{kg}$ ）であり, 移植 CFU-GM 数は中央值 $1.9 \times 10^{4} / \mathrm{kg}$ (range $0.1 \sim 25.6 \times 10^{4}$ ) であった。移植 

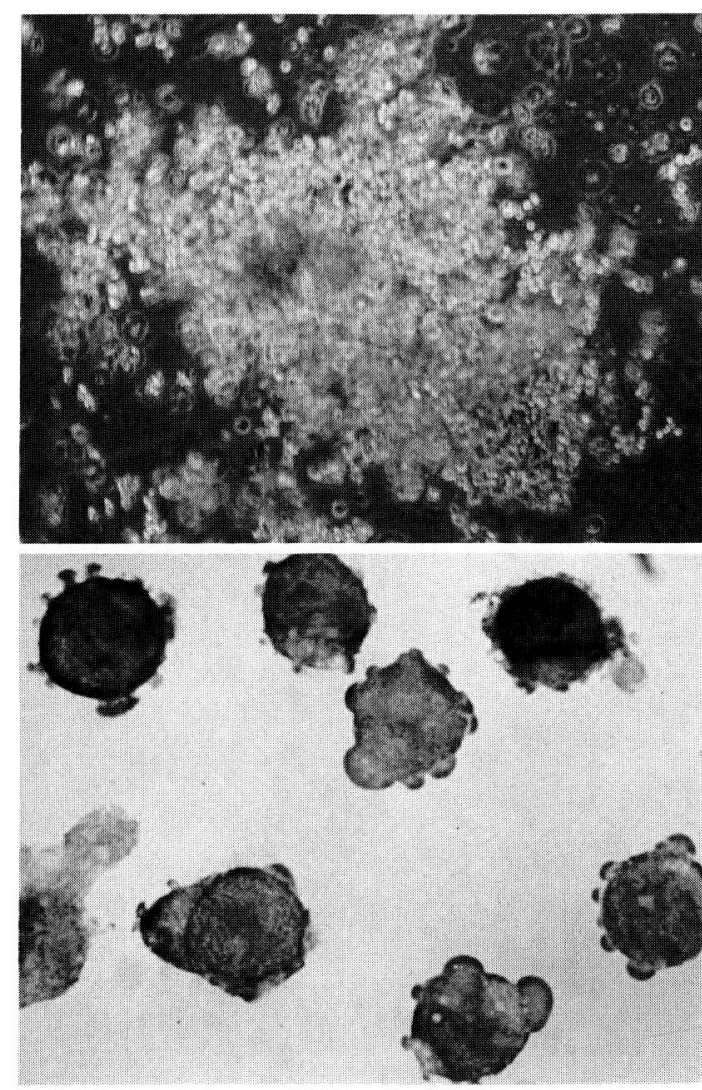

図 2 巨核球コロニーの位相差顕微鏡写真 (上段, $\times$ 100 倍)とコロニーを構成する巨核球系細胞(下段, $\times$ 800 倍)

幹細胞生着の有無は生着39/44 (89\%) であった. 好中 球数 $500 / \mu l$ 以上に達した日数は中央値22日（range 12〜46日)であり, 血小板 $50.000 / \mu l$ 以上に達した日数 は中央値48日（range 15～105日）であった. 生着不全 は 5 例にみられた。

移植不成功例の原因別内訳は graft failure 4 例, 早 期死亡 2 例, donor chimerism 2 例であった。

急性 GVHD（grade II〜IV）は生着した 4 例にみら れ, 慢性 GVHD は 2 例にみられた. 2 年以上生存率は 70\%であった。死因は veno-oculsive disease, 間質性 肺炎, 原病再発, 生着不全, 頭蓋内出血であった.

HLA が半分しか一致してない (haplo-identical) 臍 帯血を移植して生着したとの報告もある ${ }^{9)}$.このよう に, HLA が一致しなくても, 致死的な GVHD は現在 のところみられていない。これらの報告から臍帯血幹 細胞移植は骨髄移植に比較して移植有核細胞数は 5 分

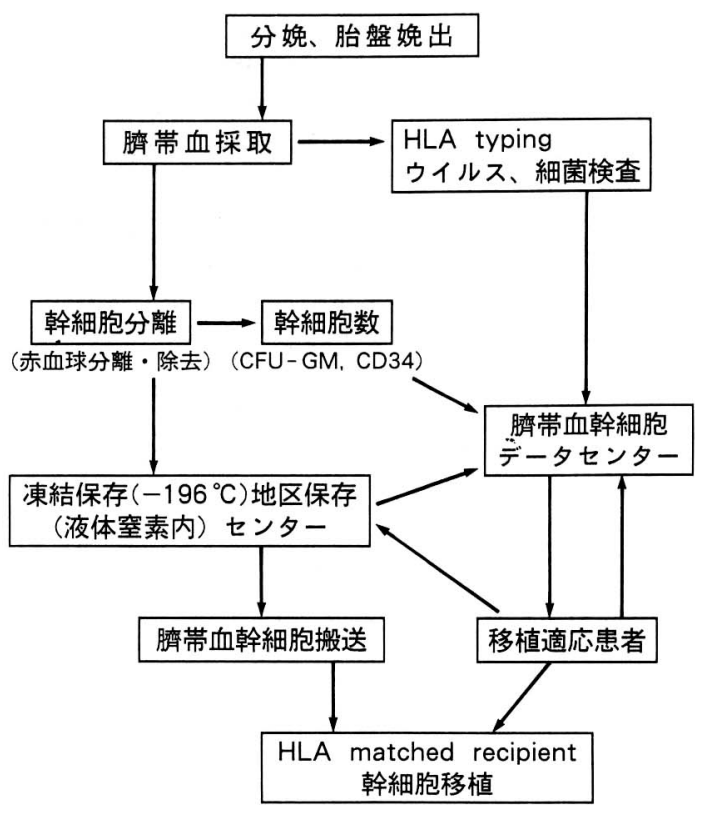

図 3 臍帯血採取・保存・移植システムの概略

の 1 から10分の 1 で生着が得られており,また HLA は一部不適合でも致死的な GVHDの発生は少ないな どの有利な側面である。

\section{6. 臍帯血バンク}

これまで述べたように小児の同胞間では臍帯血幹細 胞移植は骨髄移植に劣らない成績が得られている. そ こで, 次の段階として臍帯血幹細胞バンクを設立し, 非血縁者間でも臍帯血幹細胞移植を利用した移植が可 能になるようなシステムが出来れば，骨髄バンクのド ナー不足をある程度解消できるものと思われる7). 欧 米では臍帯血バンクを利用した移植が開始されてい る.図 3 にわれわれの考えている臍帯血バンクシステ ムを示した。これを設立するには多くの解決しなけれ ばならない問題があるが, 本邦では 1 年に約 100 万件の 分婏があるので, その10分の 1 でも臍帯血が採取でき, 保存システムが整備されたら, 小児で臍帯血移植を必 要としている患者の大部分のドナーの代わりを臍帯血 で充足するものと思われる。

したがって, 今後, 臍带血幹細胞移植は幹細胞移植 療法の分野で多大な変革をもたらすことが期待され る.

\section{文 献}

1) Broxmeyer, H.E., et al.: Human umbilical cord blood as a potentialsource of transplant 
able hematopoietic stem/progenitor cells. Prc. Natl. Acad. Sci. U.S.A., 86 : 3828-2832, 1989.

2) Wagner, J.E. : Umbilical cord blood stem cell transplantaion. Am. J. Pediat.Hematol. Oncol., 15 : 1174, 1989.

3) Gluckman, E., et al.: Hemotopoietic reconstitution in a patient with Fanconi anemia by means of umbilical-cord blood from an HLAidentical sibling. N. Engl. J. Med., 321 : 1174, 1989.

4）西平浩一，他：在胎週数別の新生児末梢血液およ び臍帯血の造血幹細胞数ならびに増殖能に関する 検討. 日小血会誌， 7:558-563, 1993.

5) Hows, J.M., et al.: Growth of human umbilical-cord blood in long term haemopoietic cultures. Lancet, 340 : 73-76, 1992.
6）西平浩一, 他：臍帯血幹細胞移植に関する研究一 胎盤臍帯より採取可能造血幹細胞数一. 日小血会 誌, 9:000-000, 1994.

7) Gluckman, E., Devergle, A., Thierry,D., et al. : Clinical applications of stem cell transfusion from cord blood and rationale for cord blood banking. Bone Marrow Transplantation, 9 (Suppl. 1) : 114-117, 1992.

8) Wagner, J.E., et al.: Umbilicl cord blood transplantation: Report of results in 50 patients. Blood, 84 (Suppl. 1) : 396a, 1994.

9) Kurtzberg, J., et al. : Hploidentical transplantation of umbilical cord blood mononuclear cells in a pediatric patient. Blood, 82 (Suppl. 1) : 634a, 1993. 